\title{
NUMERICAL MODELLING OF AIRFLOW AND TEMPERATURE DISTRIBUTION IN A LIVING ROOM WITH DIFFERENT HEAT EXCHANGE CONDITIONS
}

\author{
S. Gendelis, A. Jakovičs \\ University of Latvia, Faculty of Physics and Mathematics, Laboratory for \\ Mathematical Modelling of Environmental and Technological Processes, \\ 8 Zellu Str., Riga, LV-1002, LATVIA \\ Stanislavs.Gendelis@lu.lv
}

\begin{abstract}
Numerical mathematical modelling of the indoor thermal conditions and of the energy losses for separate rooms is an important part of the analysis of the heatexchange balance and energy efficiency in buildings. The measurements of heat transfer coefficients for bounding structures, the air-tightness tests and thermographic diagnostics done for a building allow the influence of those factors to be predicted more correctly in developed numerical models. The temperature distribution and airflows in a typical room (along with the heat losses) were calculated for different heater locations and solar radiation (modelled as a heat source) through the window, as well as various pressure differences between the openings in opposite walls. The airflow velocities and indoor temperature, including its gradient, were also analysed as parameters of thermal comfort conditions. The results obtained show that all of the listed factors have an important influence on the formation of thermal comfort conditions and on the heat balance in a room.
\end{abstract}

Key words: living room, heat losses, numerical modelling, solar radiation, thermal comfort.

\section{INTRODUCTION}

The main Latvian normative documents specifying requirements for thermal conditions of buildings are the Latvian Building Code LBN 002-01 [1] and the Law on the Energy Performance of Buildings [2]. Complex analysis of a number of impact factors is therefore to be performed and its findings optimised. Two main elements in the heat exchange processes are the conductive heat losses through the bounding structures of a building and the convective heat exchange through the openings in its envelope. Both of them can be calculated or estimated using appropriate field measurement systems and methods.

Analytical or numerical calculation of the heat transmittance properties of building structures is only possible for known materials and constructions. The use of field measurements in order to find heat transmittance $U\left(\mathrm{~W} \cdot \mathrm{m}^{-2} \cdot \mathrm{K}^{-1}\right)$ for different bounding elements is necessary in the cases when the corresponding data are not known (which is typical for most of the buildings erected in Latvia between 1950 and 1990) as well as in order to verify the calculated values for very antiquated and worn buildings. For heat transmittance field measurements under non-stationary conditions an original measurement system and data processing algorithms [3] were developed and widely used. The measurements reported in [4] 
show that the $U$ value for the building structures of old apartment houses is in the range $0.6-1.8 \mathrm{~W} \cdot \mathrm{m}^{-2} \cdot \mathrm{K}^{-1}$, thus not complying with the LBN building code [1]. For example, the experimentally estimated $U$ value for a $35 \mathrm{~cm}$ thick silicate brick wall is $1.8 \mathrm{~W} \cdot \mathrm{m}^{-2} \cdot \mathrm{K}^{-1}$, which is five times greater than the values fixed in the building code. At the same time, for newly erected buildings with lightweight walls the $U$ value can exceed $0.4 \mathrm{~W} \cdot \mathrm{m}^{-2} \cdot \mathrm{K}^{-1}$ and therefore does not comply with the requirements of this code.

Measurements of the airtightness (or air permeability) $n(1 / \mathrm{h})$ demonstrate the dominant role of convective heat transfer in the rooms with old wood-framed windows or in the buildings with lightweight outer wall frameworks. A standardised BlowerDoor device and the principles of Standard EN ISO 9972 [5] are used to examine the air exchange in a separate room or the whole building. Measurements of the kind show that the rate of uncontrolled air exchange under typical meteorological conditions for old-build houses can exceed $n=21 / \mathrm{h}$. The air supply required for buildings without forced ventilation is therefore more than threefold higher and is the cause of unnecessarily large heat losses. On the other hand, the air exchange also plays a significant role in guaranteeing the oxygen feed for the rooms inhabited by humans: the airflows through openings and the ventilation system are therefore to be analysed in detail.

Besides thermal convection, the radiation heat transfer from a heater's surface and through the windows should be taken into account for more accurate results. On sunny days, owing to considerable solar heat transfer through the windows, the required temperature in a room can be maintained with less heat from the heating system. In fact, direct solar radiation is not dominant in the Latvian climate; yet it should be taken into account when doing calculations for buildings with sizeable glass surface areas, especially for newly constructed buildings with lightweight walls. The physical location of a heater and its type (a classic radiator or a heated floor) also have an important influence on the airflow, temperature distribution and heat balance in a living room and should be analysed.

All of the above-mentioned processes determine a building's energy balance and heat losses. Various mathematical models can be employed for optimisation of the heating requirements in a building and also for the thermal comfort analysis. One can use an integral model for modelling the whole building heat balance, e.g. $[6,7]$. We however propose a different modelling approach necessary for modelling the physical processes in separate rooms. For the analysis we have chosen a typical living room with various conditions (heating system's modifications, solar source, ventilation conditions). Another important reason for the modelling is the necessity to analyse the thermal comfort conditions in such a separate room. They are generally affected by many factors $[8,9]$, so three conditions will be analysed: the velocity of airflows, the average indoor temperature and the vertical temperature gradient in the room.

\section{BACKGROUND AND MODELS}

The aim of this work was to evaluate the influence of various factors (heater location, air infiltration and solar radiation) on the distribution of temperature and airflow in the modelled office or living room and on the overall heat balance of the room using the numerical modelling (Computational Fluid dynamics or CFD) 
approach. In contradistinction to similar studies [10, 11, 12], the parameters of such a room were the chosen characteristics and were representative of existing old apartment buildings in Latvia (natural ventilation, gaps in the window-frames and high heat transmittance through windows: $U=2.5 \mathrm{~W} \cdot \mathrm{m}^{-2} \cdot \mathrm{K}^{-1}$ ).

Previous calculations of the average turbulent flows by Reynolds-averaged Navier-Stokes (RANS) equations and comparison with measurements for the test room $[10,13]$ demonstrate that the traditional $k-\varepsilon$ turbulence model produces inadequate results, especially for the boundary layers near the walls. For that reason an improved re-normalized group (RNG) approach [13] or modified computation for the near-wall area using different low Reynolds number turbulence models [14] were used. Analysis of the models' properties for various flows and in their characteristic zones shows that a substantial improvement of the RANS models can be achieved by combining the popular $k-\varepsilon$ and $k-\omega$ models.

One of the commonly used combined approaches is the shear stress transport (SST) $k$ - $\omega$ model, which has been proved to be efficient for many flow classes [15] and is included in the widely used commercial modelling software ANSYS CFX [16]. This approach has already been used for modelling the occupied living spaces [17]. Thus, the SST approach has become an informal standard for the modelling of engineered physical turbulent flows. Other non-stationary turbulent models with more detailed resolution of turbulent energy transfer vortices (e.g. large eddies simulation, LES) are at least ten times more resource-capacious than the above mentioned two-parameter models.

A possible compromise is the combination of the RANS and LES models, the so-called detached eddy simulation (DES). The SST $k$ - $\omega$ model is used in this approach for modelling the boundary layers with small turbulent eddies in the case of high Reynolds number flows. This helps to decrease the number of elements in those zones, which saves the computational resources. However, some studies [17] have indicated that, although the DES results are slightly more consistent with the experimental data, the time-averaged results from the unsteady RANS and DES approaches are quite similar. Moreover, comparison of different subgrid-scale LES models for indoor airflow [18] shows that the results obtained in the vicinity of a wall differ greatly from the measured data. These reasons are the motivation for the choice of the SST $k-\omega$ model in the modelling and numerical calculations of the living room under consideration.

Some important factors have not been included in the room's models in previous calculations, e.g. the convection through openings and gaps, buoyancydriven forces, thermal radiation, and the solar source or heater. However, all these factors have an expressed influence on the processes in a living room; therefore it is very important to perform a complex analysis of all these factors, as well as to include other factors like the solar source through the window. Different authors use various modelling software packages and approaches, and therefore it is difficult to compare results. For that reason only one approved modelling programme ANSYS CFX and a living room with fixed geometry were used for the comparison and analysis of various factors in this study. Uniform modelled region discretisation was employed for all the considered variants to reduce the impact of potential numerical effects; the necessary additional modifications - a more detailed discretisation grid and fine boundary layers were used in the regions with large velocity and temperature gradients. 


\section{FORMULATION OF THE PROBLEM}

A typical living room or office with convective boundary conditions on the exterior surfaces of bounding structures and a constant heater surface temperature were chosen for modelling. The calculations were performed for a $2.75 \times 4 \times 6 \mathrm{~m}$ room (shown in Fig. 1), filled with air. Openings in the walls for air exchange and a radiation heat transfer model with an additional solar source were also included into some modelling variants (see Table 1).

The window and the wall to the exterior air were modelled using the heat transmittance values $U=0.35 \mathrm{~W} \cdot \mathrm{m}^{-2} \cdot \mathrm{K}^{-1}$ for the wall and $U=2.5 \mathrm{~W} \cdot \mathrm{m}^{-2} \cdot \mathrm{K}^{-1}$ for the window. Such values were chosen as they are suited to a room with an insulated outer wall and an ordinary double-glazed wooden window typical of old buildings in Latvia. The heat transmittance $U$ for other boundaries (side walls to the adjoining rooms and to the corridor) was set to $1.0 \mathrm{~W} \cdot \mathrm{m}^{-2} \cdot \mathrm{K}^{-1}$. The boundary walls and window were not modelled physically; the corresponding heat transmittance $U$ was included in the coefficient $\alpha\left(\mathrm{W} \cdot \mathrm{m}^{-2} \cdot \mathrm{K}^{-1}\right)$ of heat transfer from the surfaces using the expression $\alpha=(1 / 5.9+1 / U)^{-1}$ for all solid structures [19].

It was assumed that the surrounding spaces (upstairs, downstairs and siderooms) had a temperature of $20^{\circ} \mathrm{C}$, the corridor or staircase - a lower temperature of $15^{\circ} \mathrm{C}$, and the outdoor temperature was $-10^{\circ} \mathrm{C}$ (e.g. winter conditions). Such outdoor temperatures were also used to set up the convective boundary conditions on the room's envelope: $q=-\alpha\left(T-T_{\text {out }}\right)$, where $q$ is the heat flux $\left(\mathrm{W} \cdot \mathrm{m}^{-2}\right)$ and $T$ is the temperature $\left({ }^{\circ} \mathrm{C}\right)$ on the surface.

A constant surface temperature of $50{ }^{\circ} \mathrm{C}$ was set for the convector in the variants using a classical central heating system; this assumption accords with the real situation in houses of Latvia, where the water with a constant temperature (typically $45 \ldots 55^{\circ} \mathrm{C}$ ) is used as the heat carrier in heating systems. As the airflow intensity and the air temperature near the convector have an important influence on the intensity of heat transfer from its surface, the total heating power of the convector will vary for different variants. The surface temperature was set to $25{ }^{\circ} \mathrm{C}$ for floors in the variants with floor heating.

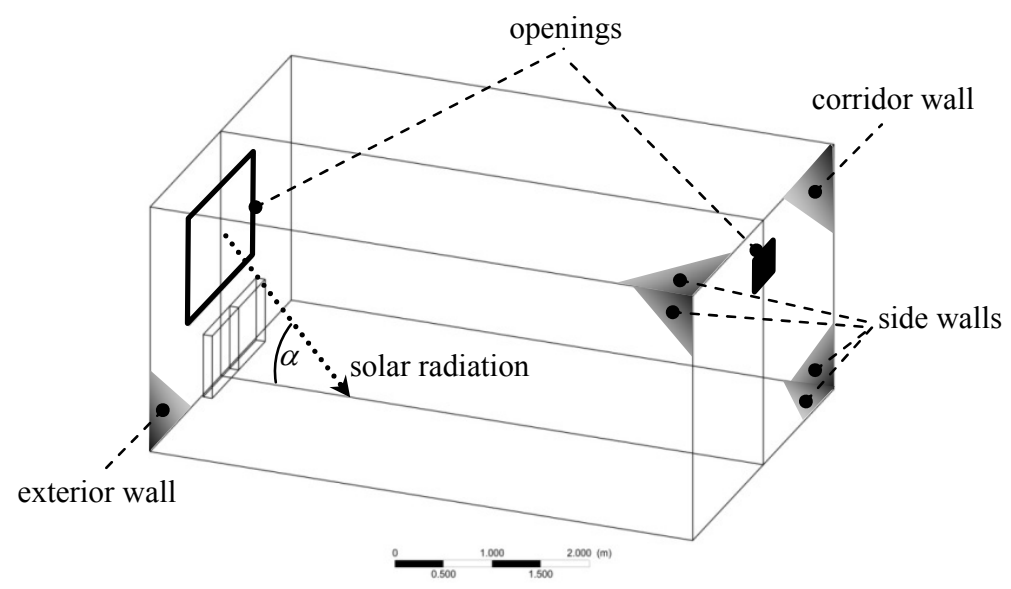

Fig. 1. Layout of the modelled room. 
Properties of various variants considered and the main results of modelling

\begin{tabular}{|c|c|c|c|c|c|c|c|c|c|c|}
\hline \multirow[b]{2}{*}{$\begin{array}{l}\text { Properties/ } \\
\text { results }\end{array}$} & \multicolumn{10}{|c|}{ Modelled variants } \\
\hline & $\begin{array}{l}0 \\
\text { D } \\
\text { I } \\
\text { I } \\
-1\end{array}$ & 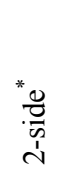 & 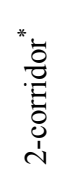 & $\begin{array}{c}{ }^{*} \overline{8} \\
\stackrel{0}{0} \\
\text { ì }\end{array}$ & 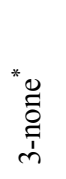 & 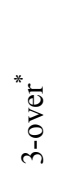 & 蒾 & 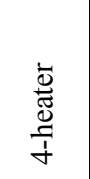 & $\begin{array}{l}00 \\
\dot{0} \\
0 \\
0 \\
\dot{1} \\
\dot{1}\end{array}$ & $\begin{array}{l}00 \\
\frac{0}{0} \\
0 \\
\dot{f}\end{array}$ \\
\hline Heater temperature $\left({ }^{\circ} \mathrm{C}\right)$ & 50 & 50 & 50 & 25 & 50 & 50 & 50 & 50 & 50 & 50 \\
\hline Pressure difference $\Delta P(\mathrm{~Pa})$ & - & 0 & 0 & 0 & 0 & 1 & -1 & - & - & - \\
\hline $\begin{array}{l}\text { Solar source's angle of } \\
\text { attack } \alpha\left({ }^{\circ}\right)\end{array}$ & - & - & - & - & - & - & - & - & 60 & 30 \\
\hline $\begin{array}{l}\text { Total heat output for the } \\
\text { heater }(\mathrm{W})\end{array}$ & 148 & 145 & 136 & 154 & 164 & 166 & 263 & $225^{* *}$ & $173^{* *}$ & $178^{* *}$ \\
\hline Conductive heat losses (W) & 148 & 124 & 87 & 124 & 55 & 97 & $-413^{* * *}$ & 225 & 401 & 589 \\
\hline Convective heat losses (W) & - & 21 & 49 & 30 & 109 & 69 & 676 & - & - & - \\
\hline Solar power $(\mathrm{W})$ & - & - & - & - & - & - & - & - & 228 & 411 \\
\hline Air exchange rate $n(1 / \mathrm{h})$ & - & 0.14 & 0.15 & 0.2 & 0.5 & 1.54 & 0.94 & - & - & - \\
\hline Average velocity $v(\mathrm{~cm} / \mathrm{s})$ & 5 & 4 & 2 & 3 & 3 & 6 & 6 & 2 & 5 & 5 \\
\hline $\begin{array}{l}\text { Average temperature } T \\
\left({ }^{\circ} \mathrm{C}\right)\end{array}$ & 21.6 & 19.2 & 18.3 & 19.0 & 18.3 & 18.5 & 13.7 & 24.2 & 28.4 & 32.5 \\
\hline $\begin{array}{l}\text { Vertical temperature } \\
\text { difference } \Delta T\left({ }^{\circ} \mathrm{C}\right)\end{array}$ & 2.2 & 1.9 & 2.0 & 0.8 & 0.7 & 0.7 & 4.1 & 2.1 & 2.5 & 1.7 \\
\hline
\end{tabular}

geometry with window-sill;

** including radiative heat flux;

*** value is negative due to positive heat input through the corridor and side walls.

Three different placements of a heater were examined - near the window (most common), near the side wall and near the wall adjacent to the corridor. Solar radiation through the window was modelled as a heat source on the inner window's surface. Given the data on typical window solar transmittance for Latvian climatic conditions in spring, the solar heat flux density for boundary conditions was set to $500 \mathrm{~W} \cdot \mathrm{m}^{-2}$. The angle of attack for solar radiation coming into the room through the window was varied from 30 to 60 degrees, thus modelling different sun altitudes. All objects (except the transparent window) were modelled as grey bodies with emission $\varepsilon=0.9$.

A small gap between the window and the wall was created in some variants to model real gaps in old window-frames: in the opposite wall, however, a ventilation opening was created (Fig. 1). Boundary conditions with a constant pressure and temperatures of $-10{ }^{\circ} \mathrm{C}$ and $15^{\circ} \mathrm{C}$ were defined for the opening in the window-frame and ventilation openings, respectively. The pressure difference $\Delta P$ between openings in the wall to the corridor and outer wall $\left(\Delta P=P_{\text {corridor }}-P_{\text {outer wall }}\right)$ was set 0,1 or $-1 \mathrm{~Pa}$, to model different wind conditions. The non-slip boundary conditions were used for all surfaces except openings. The room's geometry did not contain a window-sill for the base variant and solar radiation modelling, but it existed in all other variants. 
The features of all the variants are summarised in Table 1 . The base variant '1-base' represents a living room without air infiltration and solar radiation and with the heater placed near the window.

The next three variants, '2-side', '2-corridor' and '2-floor', correspond to the three different heater placements and types: near the side-wall, near the wall adjacent to the corridor, and the floor heating system without a standard convector. Air infiltration through the openings in the boundary structures (around the window and in the opposite wall - see Fig. 1) was also accounted for to make the models closer to the real situation.

For the next three variants a base room with changeable air infiltration was considered, allowing estimates of the influence of winds around the building on the conditions in a living room. Three different boundary conditions were set for the openings - variant ' 3 -none' without a pressure difference $(\Delta P=0 \mathrm{~Pa})$, variant '3over' with $1 \mathrm{~Pa}$ relative overpressure in the room, and variant ' 3 -under' with $1 \mathrm{~Pa}$ relative underpressure in the room. The terms 'overpressure' and 'underpressure' are used to describe the direction of the pressure difference relative to the exterior air pressure. When the pressure on the opening in the exterior wall is lower than that on the wall adjacent to the corridor it is called 'overpressure' (relative to the exterior air), while in the case of 'underpressure' the pressure on the opening in the exterior wall is greater than that on the wall adjacent to the corridor.

The last three variants include the radiation modelling from the heater's surface only ('4-heater'), and also solar heat transfer through the window with a $60^{\circ}$ ('4-60 deg') or $30^{\circ}$ ('4-30 deg') angle of radiation direction, which implies an additional heat source on the window surface. Radiation should be taken into account by modelling the objects with high temperatures (like the heater); besides, solar radiation is a very important additional heat source on sunny days. The results of a previous analysis of a living room with variable $U$ values for boundary structures and different heater temperatures are described in [20].

The airflows in the room depend both on the convection created by the temperature difference and on the air exchange between the openings in the structures for some variants. To describe the quasi-stationary behaviour of the temperature and the average turbulent flows, traditional differential equations are employed [21]:

- Reynolds averaged momentum equation with SST $k$ - $\omega$ turbulence model [22];

- continuity equation;

- energy conservation equation.

ANSYS CFX software [16] was used for the development of 3D mathematical models of the living room, volume discretisation, numerical calculations and analysis of results. The built-in Monte-Carlo model was used for the radiation simulation in the last three variants. This radiation model was employed for two reasons:

- the air in the room is transparent to radiation at wavelengths at which the majority of the heat transfer occurs; therefore, the radiation only affects the medium by heating the surfaces, with no radiant energy transfer directly to the medium;

- the directional solar radiation source cannot be specified in other available models. 
The convective boundary conditions of the third type and the low viscosity of buoyancy-driven air essentially worsen the convergence of an iteration process. Each modelling simulation was therefore performed in two steps - first, a steadystate calculation; then a transient state with constant properties and initial conditions based on the steady-state results. Calculations were performed for $10 \mathrm{se}-$ conds with $1 \mathrm{~s}$ time step, and the results obtained were averaged over time. The total time required for calculations of one variant with a $3 \mathrm{GHz}$ computer was from 24 to $48 \mathrm{~h}$ depending on the discretisation and boundary conditions. The calculated heat imbalance between the heater power, the solar source and the losses from the outer surfaces and openings was less than $3 \%$.

Discretisation was performed using tetrahedral elements of varying size; for boundary layers this was done with smaller prismatic elements. The characteristic size of finite elements was from $20 \mathrm{~cm}$ in the middle of the room to $0.5 \mathrm{~mm}$ in the vicinity of the heating element and for the openings in the walls: the total number of elements was therefore up to $7 \cdot 10^{5}$ depending on the geometry. The typical meshes in the middle cross-section of the room and near the heater are shown in Fig. 2.

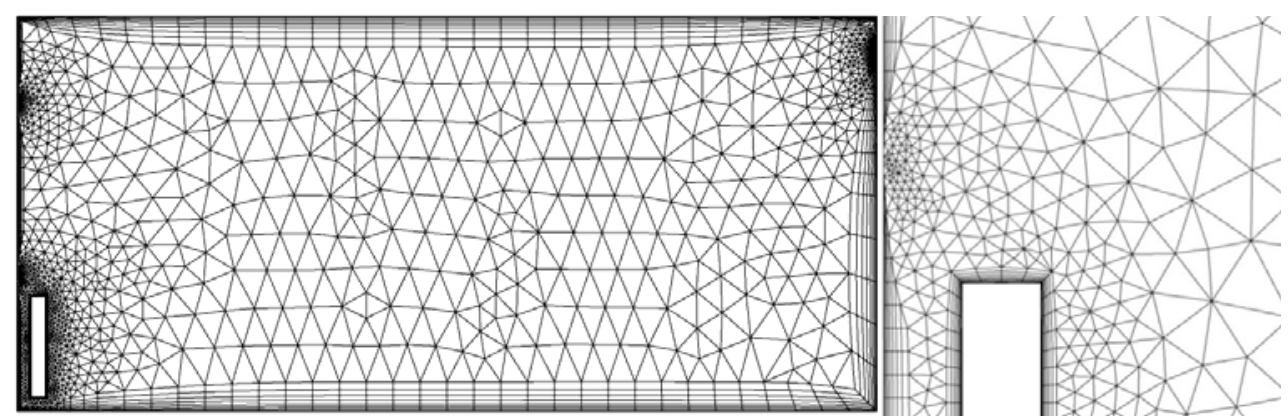

Fig. 2. Typical meshes for the modelled room in the middle cross-section and near the heater.

\section{GRID SENSITIVITY STUDIES}

As no experimental measurements were used to validate the model, the grid sensitivity studies were performed to estimate the impact of grid changes on the results. Three different grids were used for one typical room model without openings in the boundary structures. Radiation modelling was also included in the calculations.

Parameters for the first mesh (mesh A) corresponded to the parameters employed in other calculations described in this paper. Mesh B was created using more detailed space and surface discretisation, with a typical characteristic size of finite elements in the middle of the room equal to $15 \mathrm{~cm}$, and mesh $\mathrm{C}$ was created for a finer surface grid and more detailed boundary layers. The parameters used for all three cases are summarised in Table 2. Thereby, the total number of the elements in the modelled room increased more than 7 times (up to $5.1 \cdot 10^{6}$ ) and discretisation of the heater's surface - more than 11 times. Meshes at the bottom of the heater are visualised in Fig. 3, where mesh A is shown on the left and mesh C on the right. 


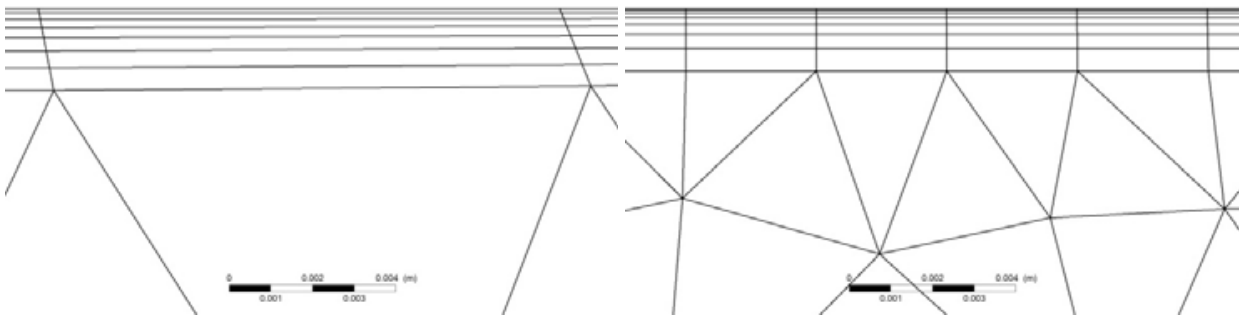

Fig. 3. Mesh changes near the heater for grid sensitivity studies.

Mesh parameters and general results for grid sensitivity study

\begin{tabular}{|l|c|c|c|}
\hline \multicolumn{1}{|c|}{ Parameter/results } & mesh A & mesh B & mesh C \\
\hline Total number of elements & 770000 & 2960000 & 5070000 \\
\hline Number of elements on heater's surface & 12100 & 50900 & 140400 \\
\hline Minimum/maximum edge length on heater's surface $(\mathrm{mm})$ & $5 / 10$ & $2.5 / 5$ & $1.5 / 3$ \\
\hline Heat output from the heater $(\mathrm{W})$ & 345 & 338 & 333 \\
\hline Minimum temperature between heater and outer wall $\left({ }^{\circ} \mathrm{C}\right)$ & 21.7 & 21.4 & 21.6 \\
\hline Characteristic air movement intensity near the window $(\mathrm{cm} / \mathrm{s})$ & 48.9 & 48.7 & 49.2 \\
\hline
\end{tabular}

Increasing the number of elements also significantly added to the calculation time and the computer memory. Thus, the numerical calculations with mesh $\mathrm{C}$ lasted more than 3 days on a $3 \mathrm{GHz}$ computer with 4 processor cores and $3 \mathrm{~GB}$ of RAM.

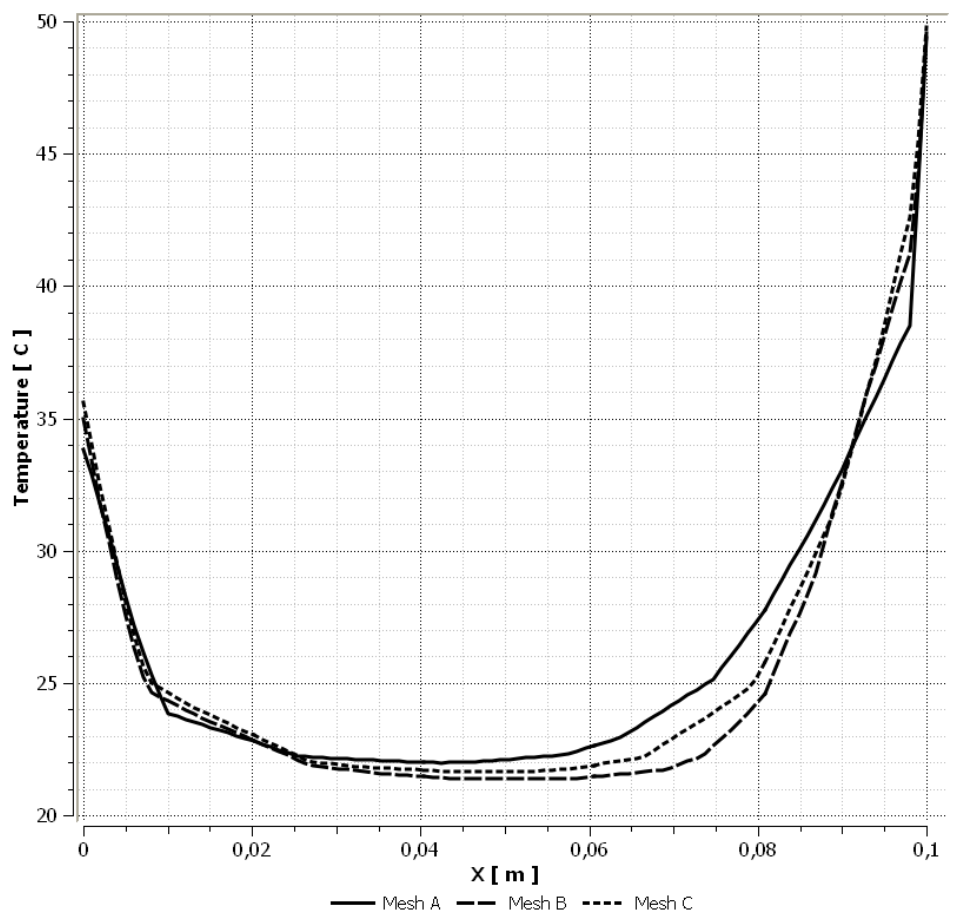

Fig. 4. Temperature profile between outer wall and heater for grid sensitivity studies. 
Some significant results for the model calculations using different meshes are shown in Table 2. As can be seen, the heating power for the room varied from $345 \mathrm{~W}$ for mesh A to $333 \mathrm{~W}$ for mesh $\mathrm{C}$, hence, a difference is less than $5 \%$. Very small changes $(0.5 \mathrm{~cm} / \mathrm{s})$ in the airflow intensity were also observed near the inner surface of the window with a large temperature gradient. At the same time, the average air temperature in the zone with the highest heat exchange - between the outer wall and the heater - barely changed and was in the range $21.4-21.7^{\circ} \mathrm{C}$. The temperature profiles shown in Fig. 4 demonstrate the acceptable small changes in numerical solutions for different mesh cases; in addition, the high temperature values at the outer wall $(x=0 \mathrm{~m})$ due to radiation from the nearby heater $(x=$ $0.1 \mathrm{~m}$ ) did not vary more than $2{ }^{\circ} \mathrm{C}$.

The studies on the grid sensitivity show that the results obtained with a 7 times finer mesh were very similar, the differences in quantitative values were negligible (in the range of 5\%), and that the qualitative airflow structure was analogous. Hence, one can conclude that the grid sensitivity was sufficient, enabling the use of a model with the default coarse mesh and less computational resources for numerical calculations in this investigation.

\section{PROBLEM SOLUTION}

\subsection{General results}

The most important results regarding the energy consumption and comfort condition parameters for all ten developed variants are summarised in Table 1 and visualised in Figs. 5 and 6. The modelling results are grouped as follows:

- base model ('1-base');

- heater placement and type ('2-side', '2-corridor', '2-floor');

- pressure difference option ('3-none', '3-over', '3-under');

- radiation modelling ('4-heater', '4-60deg', '4-30deg'). variants:

It is also possible to extract two significant aspects of the results for all

- the heat balance of the room (heating power, convective and conductive heat losses and solar power). Since the heat transmittance of boundary structures and the temperatures outside the room were fixed, the changes in conductive heat through the boundary structures were dependent on all other heat amounts;

- the characteristic values of the thermal comfort conditions (average velocity and temperature, vertical temperature difference). It was assumed that the airflow velocity should be as small as possible (not exceeding $20 \mathrm{~cm} / \mathrm{s}$ ), the maximum allowable vertical temperature gradient should be $3^{\circ} \mathrm{C}$, and the air temperature in the room - in the range $19-23{ }^{\circ} \mathrm{C}[8,9]$.

For the basic variant ('1-base') the average temperature in the room was $21.6{ }^{\circ} \mathrm{C}$ and there was a characteristic hot airflow at the top of the heater near the window (Fig. 7-1). The average airflow velocity in the room was $5 \mathrm{~cm} / \mathrm{s}$, the vertical temperature difference was about $2{ }^{\circ} \mathrm{C}$, and the thermal comfort conditions were satisfied. The total heating power for this variant without radiation modelling was $148 \mathrm{~W}$. 


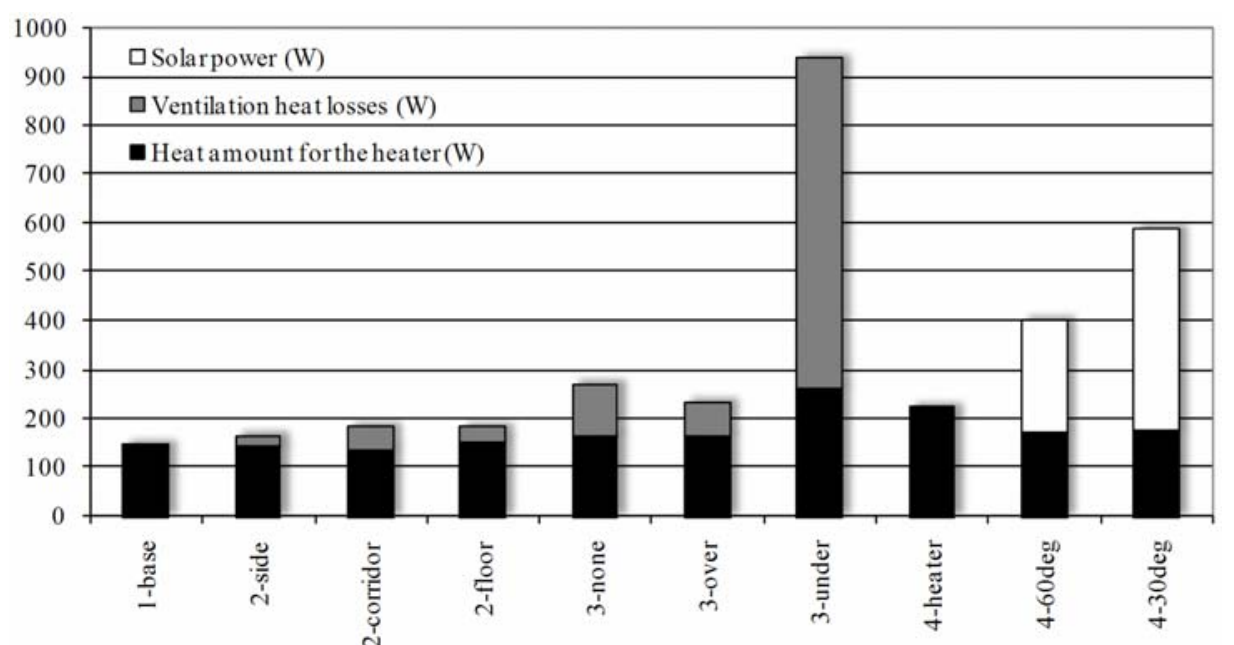

Fig. 5. Heating and solar powers and ventilation heat losses.

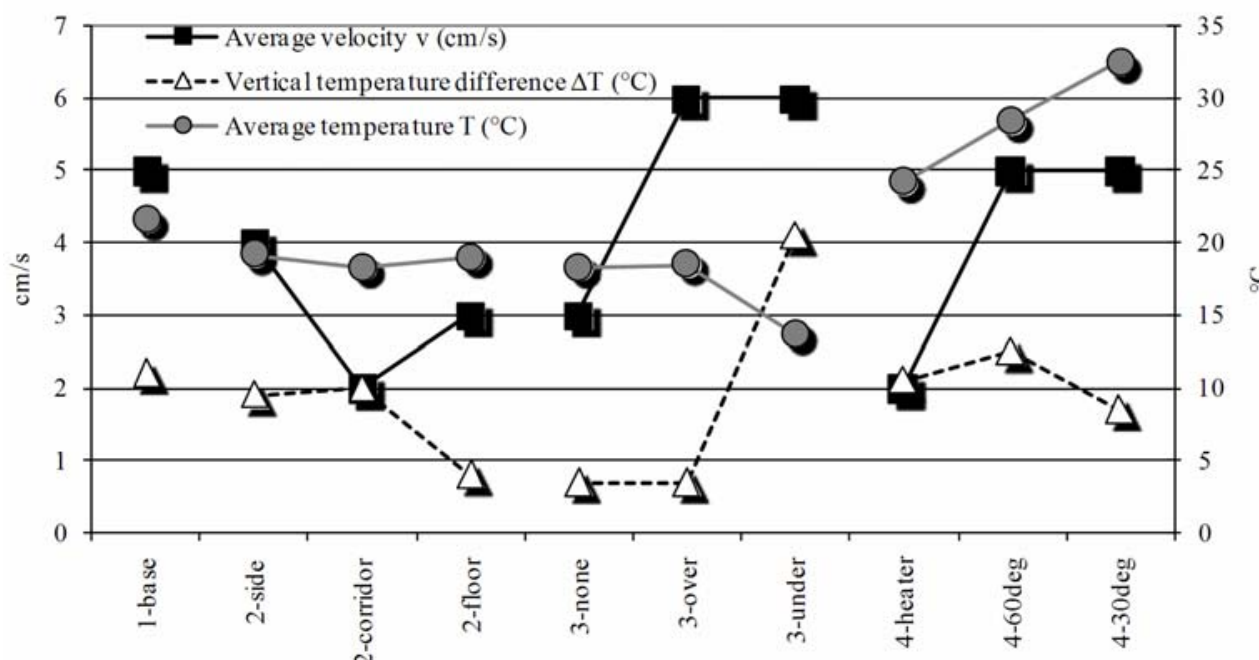

Fig. 6. Average airflow velocity, vertical temperature difference in the middle of the room and average temperature for different variants.

The various heater installations (Figs. 7-2, 7-3 and 7-4) slightly changed the heating power, and, at the same time, the average velocity in the room noticeably decreased (especially in the variant '2-corridor'). As there was a slow airflow through the openings, and a window-sill changed the air motion, the average temperature in the room decreased, which also meant smaller conductive heat losses. The best variant from the viewpoint of temperature stratification was the room with a floor heating system, in which the vertical temperature difference was reduced to $0.8^{\circ} \mathrm{C}$ and the heat surface was the entire floor area. The heating power in the variant with floor heating was higher at a lower heater temperature (Table 1) due to the greater surface area of the floor and different airflow structure and intensities. If no heater was placed near the exterior wall, the biggest disadvantage was intensive cold air inflow through the gaps in the window-frame. 

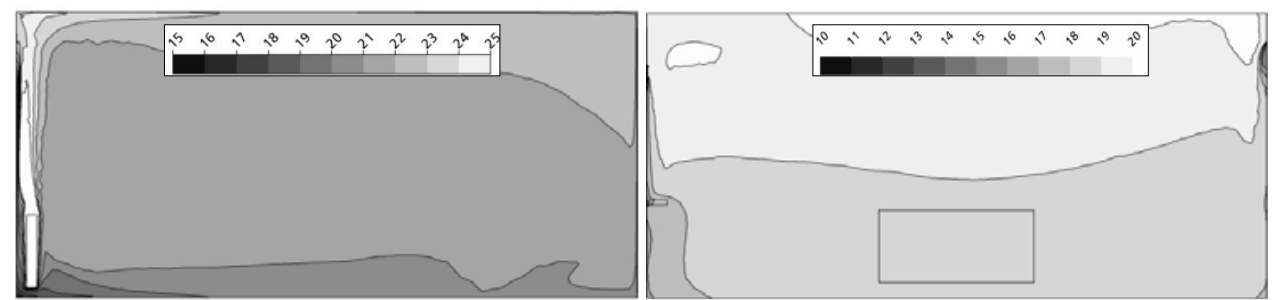

3

4

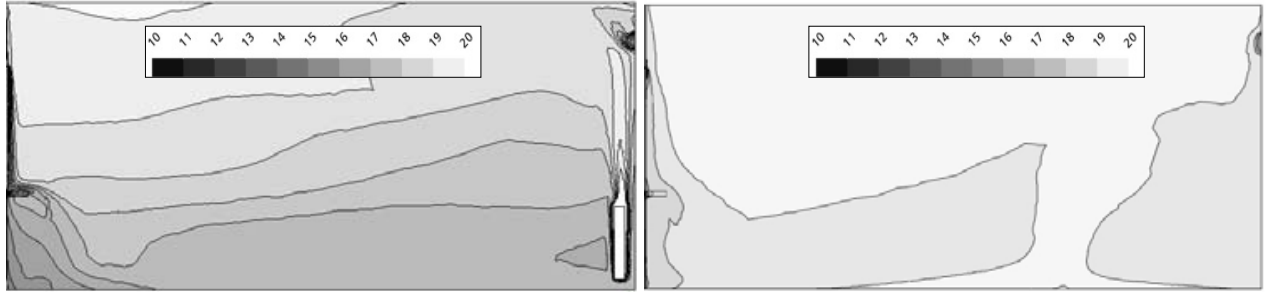

5

6

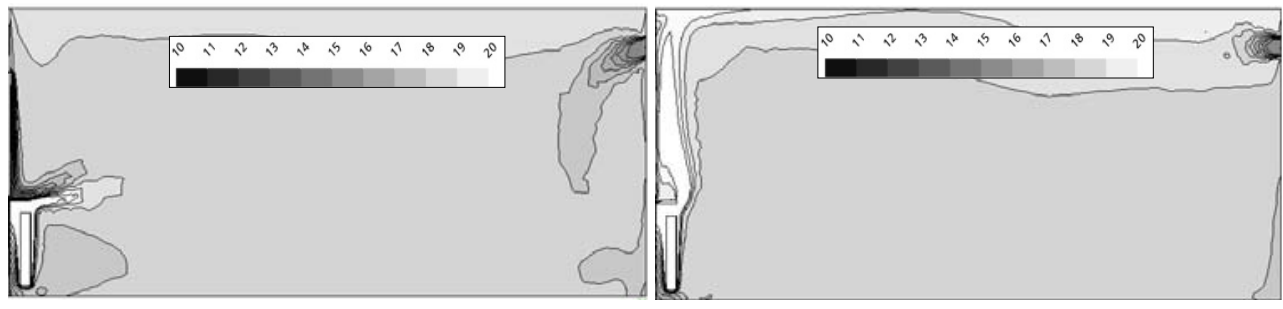

7

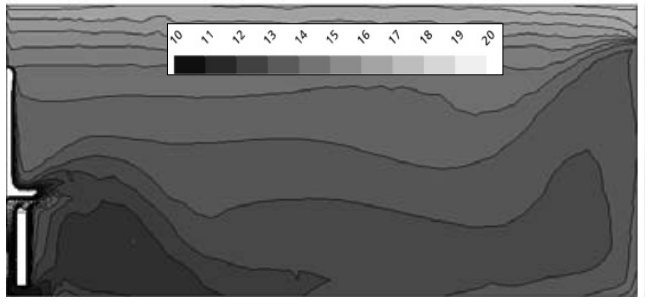

9

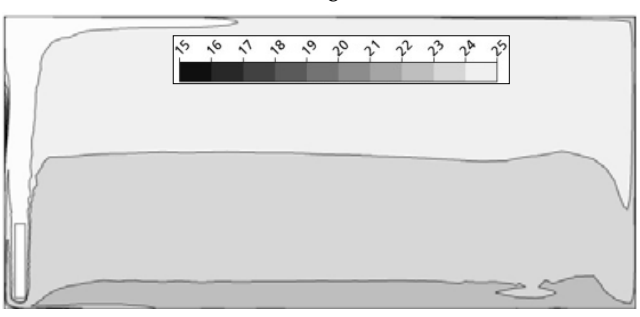

10
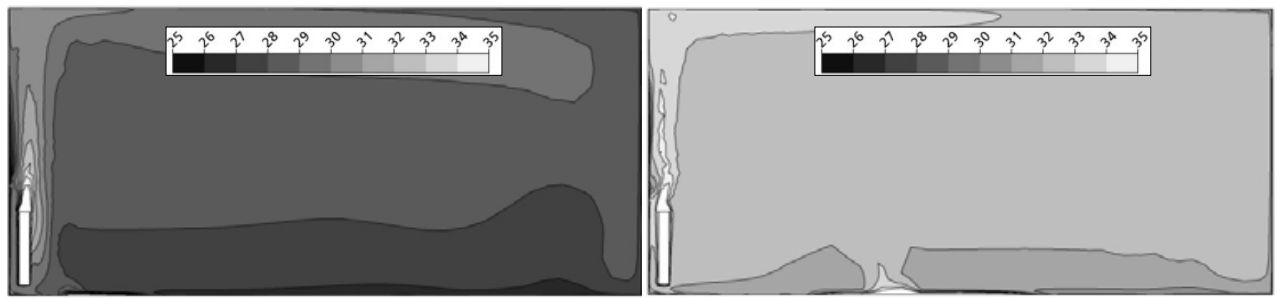

Fig. 7. Temperature distribution in the vertical symmetry plane for all modelled variants: 1 - '1-base', 2 - '2-side', 3 - '2-corridor', 4 - '2-floor', 5 - '3-none', 6 - '3-over', 7 - '3-under', 8 - '4-heater', 9 - ‘4-60deg', 10 - ‘4-30deg'.

Three options with regard to the air infiltration conditions in the room were considered in variants '3-none', '3-over' and '3-under' (Figs. 7-5, 7-6 and 7-7). When a pressure difference of $0 \mathrm{~Pa}$ was set between the ventilation opening and the gaps in the window-frame, there was an insignificant air circulation owing to thermo-convection in the room, and the air exchange rate was $0.51 / \mathrm{h}$. This value is acceptable for the oxygen inflow required for human occupancy and does not 
produce great heat losses. When the pressure on the ventilation opening was $1 \mathrm{~Pa}$ greater than that of exterior air ('3-over'), the air masses with constant temperature of $15{ }^{\circ} \mathrm{C}$ were flowing into the room from the corridor. This created an intensive flow in the middle of the room and the average velocities were high there (up to $6 \mathrm{~cm} / \mathrm{s}$ ). The variant ' 3 -under' describes a room with $1 \mathrm{~Pa}$ underpressure relative to the exterior air, which meant that the active cold exterior air with a temperature of $-10{ }^{\circ} \mathrm{C}$ was flowing into the room. As a result of more intensive airflows, the heat transfer from the radiator showed a remarkable increase - from $164 \mathrm{~W}$ with the zero pressure difference to $263 \mathrm{~W}$ in this variant. Convective heat losses owing to air infiltration were almost three times higher $(676 \mathrm{~W})$ and therefore were disadvantageous in the energy terms. Cold masses from the outside in this variant decreased the average temperature in the room to $13.7^{\circ} \mathrm{C}$. In these conditions, the surrounding rooms with a temperature of $20^{\circ} \mathrm{C}$, and even the corridor at $15^{\circ} \mathrm{C}$, worked as additional heat sources, which partially compensated for the large convective losses, and therefore the conductive heat losses through the boundary structures for this variant were negative. The vertical temperature difference doubled to $4.1{ }^{\circ} \mathrm{C}$.

The last three variants considered (Figs. 7-8, 7-9 and 7-10) showed a vital influence of the radiation from hot surfaces on the total heat balance, and this kind of heat transfer cannot be ignored for accurate qualitative results. The emission coefficient, $\varepsilon=0.9$, set for the heater's surface is in fact higher than for real heaters and demonstrated the maximum potential radiative energy output. The variant '4heater' only included the radiation heat transfer from a hot surface, and it increased the total heat output from the heater to $225 \mathrm{~W}$ (more than 50\%) and the average temperature in the room - to $24.2{ }^{\circ} \mathrm{C}$; the average velocities also increased, but the vertical temperature distribution did not change noticeably. The results of the variants with solar sources show that the solar radiation power was higher at an angle of attack of $30^{\circ}$ because the sun was shining deeper into the room (see Figs. 8 and 9). The average temperature in the variant with a $60^{\circ}$ angle of solar source was therefore $28.4^{\circ} \mathrm{C}$, while in variants with a $30^{\circ}$ angle it was four degrees higher.

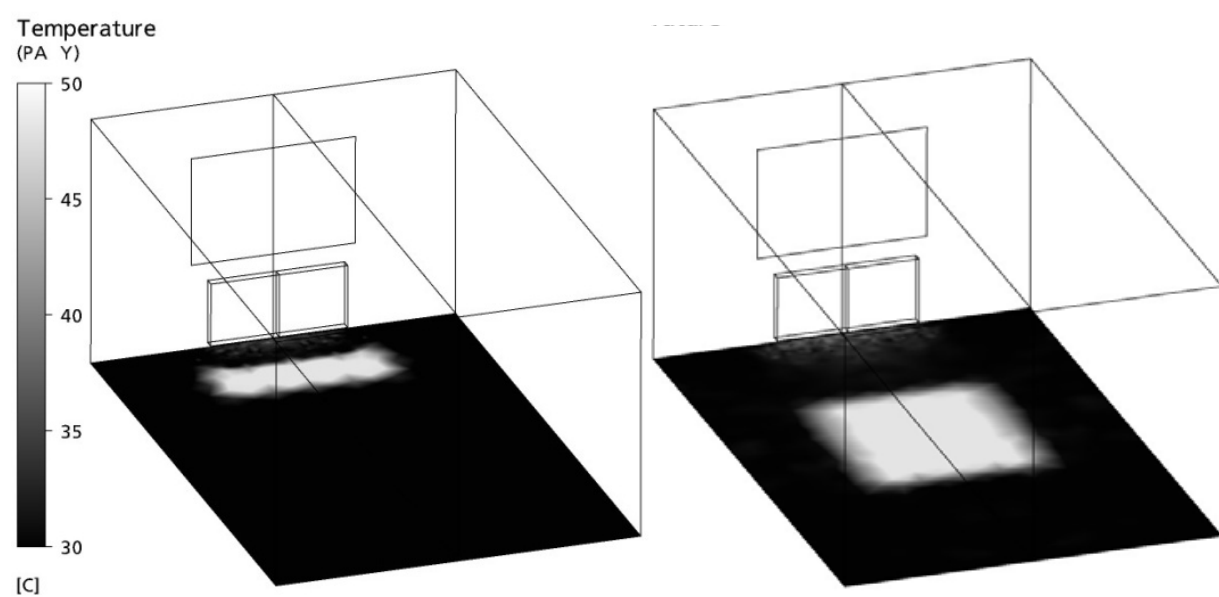

Fig. 8. Temperature distribution on the floor for variants '4-60deg' (left) and '4-30deg' (right) demonstrates the impact of solar source. 


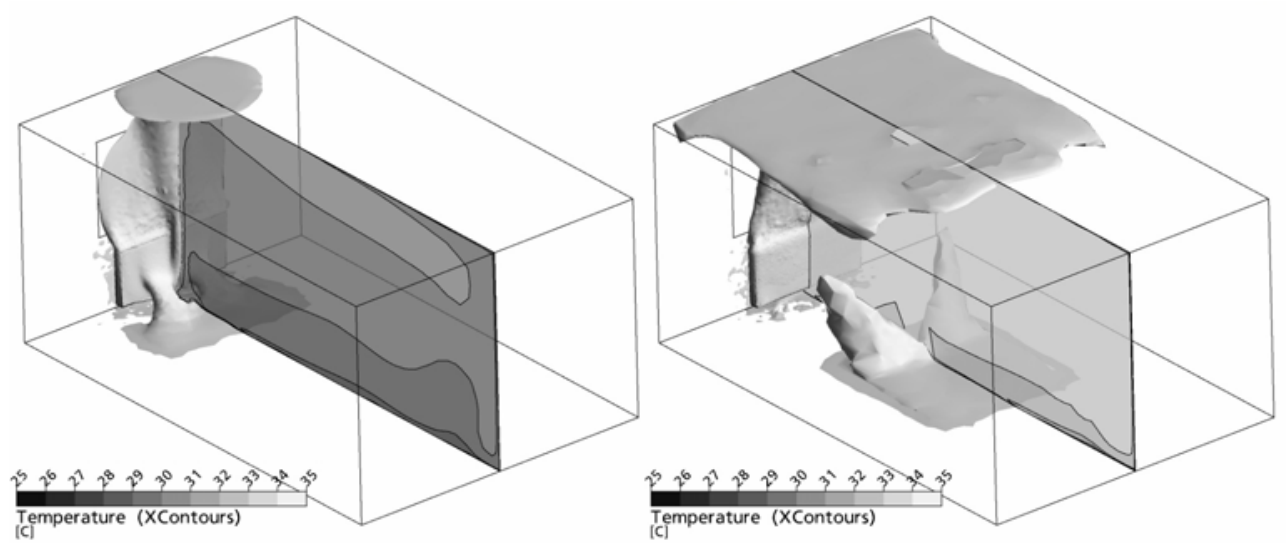

Fig. 9. Temperature isosurfaces of $30^{\circ} \mathrm{C}$ and $32^{\circ} \mathrm{C}$ for variants '4-60deg' (left) and '4-30deg' (right).

The heat output from the radiator was almost the same and the high temperature was determined only by solar radiation. The significant increase in conductive heat losses (up to 4 times compared to the base variant) was caused by the increased temperature in the room. The temperature on the floor exceeded $50{ }^{\circ} \mathrm{C}$ (Fig. 8) in the area under direct sunlight, and the temperature level in the room in this situation was not acceptable; thermostatic control of the heating system or installation of a ventilation system would be necessary to decrease the temperature in the room.

\subsection{Analysis of the results}

The thermal conditions in a room are related to the structure of airflow velocities, the pressure difference between openings in boundary constructions, the temperature distribution and the thermal convection; thus, an intensive upward airflow formed at the top of the convector with the maximum velocities up to $60 \mathrm{~cm} / \mathrm{s}$ (Fig. 10), and, at the same time, the average air motion in the whole room did not exceed 5-6 cm/s. The airflows were not as intensive for the variants with floor heating because of the lower temperature gradients. In the case of solar radiation, the hot area on the floor produced sizeable convection and increased the average air velocities in the room. In general, radiation through the window increased the airflow intensity in the middle part of the room (Fig. 10).
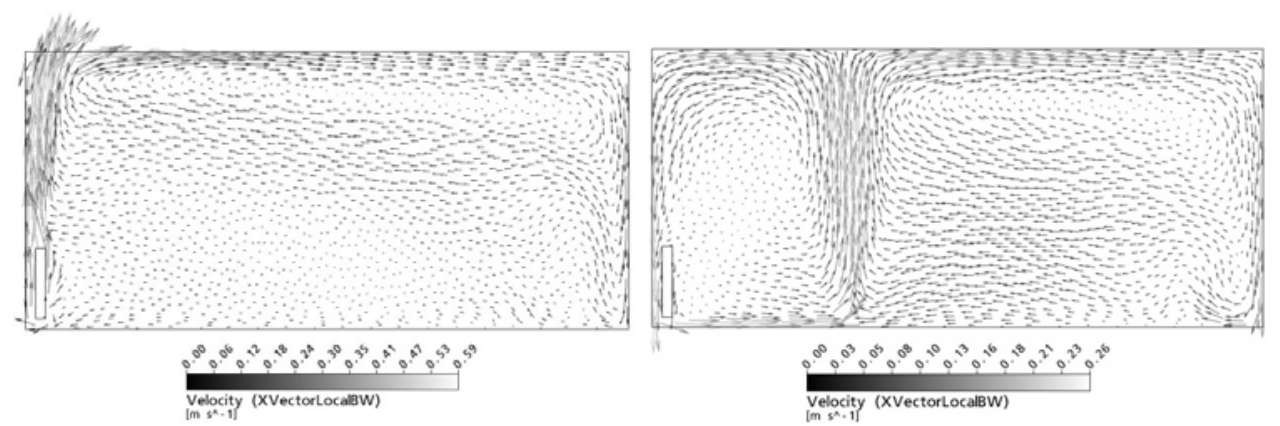

Fig. 10. Characteristic velocity vector field in the vertical symmetry plane for variants with convector heating (left) and floor heating (right) 
A complicated multiple vortex airflow structure in the room formed in the variants with air infiltration and the zero $(0 \mathrm{~Pa})$ pressure difference (Fig. 11). This was caused by three main factors:

- inflowing air from the corridor with $T=15^{\circ} \mathrm{C}$ descends near the wall;

- hot airflow from the heater moves upwards and creates the intensive vortex;

- cold exterior air flows through the gaps in the window-frame along the windowsill.

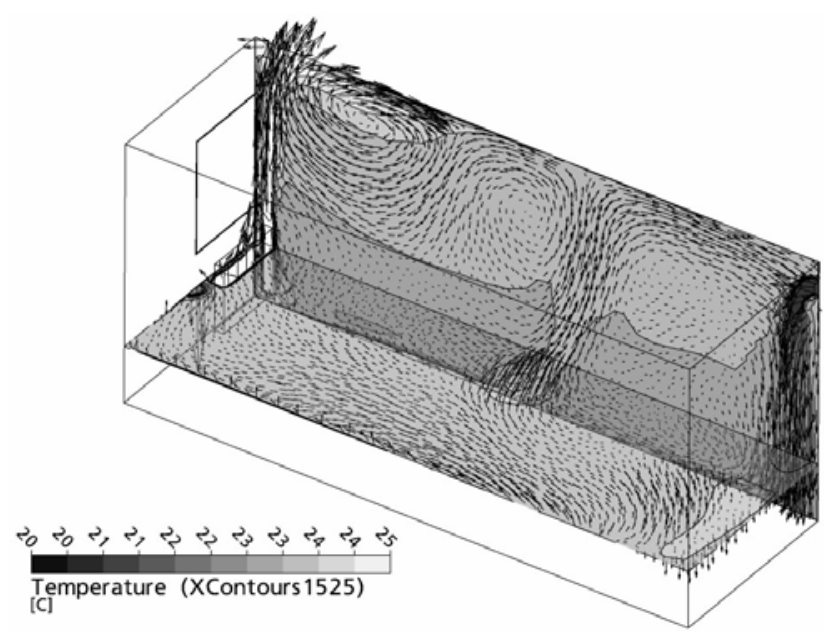

Fig. 11. Velocity vector field and temperature contours in horizontal and vertical cross sections in the case with $0 \mathrm{~Pa}$ pressure difference.

The same velocity field formed in the room in the case of underpressure, but owing to an active exterior air inflow, the temperature level was very low. The situation changed with an overpressure of $1 \mathrm{~Pa}$, when only one main vortex formed in the room owing to the active air inflow from the corridor (Fig. 12). As the air masses moved through a relatively small ventilation opening, their velocities were very high - up to $1 \mathrm{~m} / \mathrm{s}$, while the air motion in the room's other part for variants with a $1 \mathrm{~Pa}$ pressure difference did not exceed $6 \mathrm{~cm} / \mathrm{s}$.

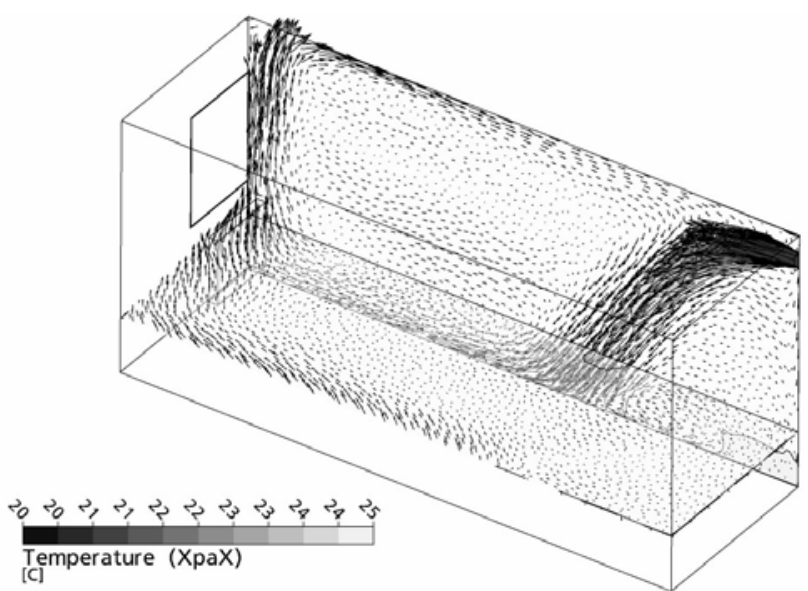

Fig. 12. Velocity vector field and temperature contours in horizontal and vertical cross-sections in the case with $1 \mathrm{~Pa}$ pressure difference. 
The established air exchange rate was sufficient for human habitation in the cases with air infiltration and the heater placed near the outer wall (variants ' 3 none', '3-over' and '3-under'), but was insufficient in all previous variants with different heater placements (variants '2-side', '2-corridor' and '2-floor') - see Table 1. It should be noted that in a living room the airflow caused by the occupants' coming-in and going-out is substantial and should be taken into account for the more precise simulations in further development of a model - such activities will increase the air exchange rate, also affecting the convective heat losses.

The room's average temperature in all variants with air infiltration and without a solar energy source ('2-side', '2-corridor', '2-floor', '3-none', '3-over' and ' 3 -under') was less than $20^{\circ} \mathrm{C}$, so the imbalance between the energy consumption and the registered heat losses was compensated by a heat flux from the neighbouring rooms with fixed temperatures of $20^{\circ} \mathrm{C}$. In the variant ' 3 -under', the temperature was below $15^{\circ} \mathrm{C}$ and there was also a heat flux from the corridor.

Another important aspect is the water condensation on the inner surface of boundary structures in the living room due to high humidity - this process may be very significant in the case of low outdoor temperatures (e.g. in winter) and high heat transmittance of the building structures. The highest risk of condensation on the outer wall was observed in two of the modelled variants - '2-corridor' and '3under' (Fig. 7). In both the variants a very low temperature was observed near the wall due to intensive cold exterior air inflow through a gap in the window-frame. Therefore, placement of a heater close to the opposite wall and a relative underpressure in a room can cause condensation or even frost on the exterior wall in the winter.

\section{CONCLUSION}

Calculations performed for different variants of a living room have clearly demonstrated the important influence of many factors, such as the placement of a heater and its type, possible air infiltration through the room's envelope, and solar radiation sources affecting the heat balance and thermal comfort conditions in the room. The modelling allows estimation of the temperature, airflow distribution and the tendencies of the changes, as well as the dependence on energy losses through the boundary structures under different conditions. Inclusion of radiation and a solar heat source in the 3D modelling of a living room is very important for a more realistic prediction of qualitative and quantitative heat transfer and convection processes taking place there.

It is possible to conclude from the modelling results that the best energy efficiency and thermal comfort conditions in a living room can be achieved in the following cases:

- when there is an under-floor heating system;

- when there is a minor overpressure relative to the exterior air to exclude cold exterior air inflow and to guarantee the air exchange $(<0.5 \mathrm{~Pa})$;

- when the heater's power is regulated in accordance with the solar radiation intensity and indoor temperature;

- when the temperature difference in the adjoining rooms is as small as possible. 
If the above-mentioned conditions are fulfilled, intensive airflows will not form, and the average temperature in the room will be acceptable for thermal comfort, with the amount of energy needed to heat the room remaining the same or increasing only slightly.

\section{REFERENCES}

1. Latvian Building Code 002-01. Thermal Performance of Building Envelope, Regulations of the Cabinet of Ministers of Latvia. (2006). Latvijas Véstnesis 3524, (in Latvian).

2. Law on the Energy Performance of Buildings, Regulations of the Cabinet of Ministers of Latvia. (2006). Latvijas Véstnesis 3835 (in Latvian).

3. Jakovičs, A., Gendelis, S., \& Krievāns, Z. (1999). Determination of the heat transfer coefficient of construction elements for existing buildings. In: Proceedings of the Third Baltic Heat Transfer Conf., Gdansk (Poland).

4. Gendelis, S., \& Jakovičs, A. (2005). Heat transfer measurements in non-stationary conditions for building structures. In: Proceedings of the 14th International Conf. on Thermal Engineering and Thermogrammetry, Budapest (Hungary).

5. ISO 9972:2006 (2006). Thermal insulation - Determination of building airtightness Fan pressurization method.

6. EN 832:1998 (1998). Thermal Performance of Buildings - Calculation of Energy Use for Heating - Residential Buildings.

7. DIN 4108-6 (2003). Thermal protection and energy economy in buildings. Part 6: Calculation of annual heat and energy use.

8. ISO 7730:2005 (2005). Ergonomics of the thermal environment - Analytical determination and interpretation of thermal comfort using calculation of the PMV and $P P D$ indices and local thermal comfort criteria.

9. Charles, K.E. (2003). Fanger's Thermal Comfort and Draught Models (Report RR162). Ottawa, Canada: Institute for Research in Construction.

10. Potter, S.E., \& Underwood, C.P. (2004). A modelling method for conjugate heat transfer and fluid flow in building spaces. Building Service Engineering Research and Technology, 25 (2), 111-125. doi: 10.1191/0143624404bt092oa

11. Djunaedy, E., Hensen, J.L.M., \& Loomans, M.G.L.C. (2004). Selecting an appropriate tool for airflow simulation in buildings. Building Service Engineering Research and Technology, 25 (3), 269-278. doi: 10.1191/0143624404bt109oa

12. Bojic, M., Yik, F., \& Lo, T.Y. (2000). Locating air-conditioners and furniture inside residential flats to obtain good thermal comfort. Energy and Buildings, 34 (7), 745 751. doi: 10.1016/S0378-7788(01)00143-8

13. Evola, G., \& Popov, V. (2006). Computational analysis of wind driven natural ventilation in buildings. Energy and Buildings, 38 (5), 491-501. doi: 10.1016/j. enbuild. 2005.08.008

14. Ji, Y., \& Cook, M.J. (2007). Numerical studies of displacement natural ventilation in multi-storey buildings connected to an atrium. Building Service Engineering Research and Technology, 28 (3), 207-222. doi: 10.1177/0143624407077190

15. Vieser, W., Esch, T., \& Menter, F. (2002). Heat transfer predictions using advanced two-equation turbulence models (CFX Technical Memorandum CFX-VAL10/0602). Offerfing, Germany: AEA Technology.

16. ANSYS Inc. (2006). ANSYS CFX User Manual.

17. Deevy, M., Sinai, Y., Everitt, P., Voigt, L., \& Gobeau, N. (2008). Modelling the effect of an occupant on displacement ventilation with computational fluid dynamics. Energy and Buildings, 40 (3), 255-264. doi: 10.1016/j.enbuild.2007.02.021 
18. Su M., Chen, Q., \& Chiang, C.-M. (2001). Comparison of different subgrid-scale models of large eddy simulation for indoor airflow modelling. J.of Fluids Engineering, 123 (3), 628-639. doi: 10.1115/1.1378294

19. ISO 6946:2007 (2007). Building components and building elements - Thermal resistance and thermal transmittance - Calculation method.

20. Gendelis, S., \& Jakovičs, A. (2003). Numerical modelling of airflow and temperature distribution in heated rooms. Latv. J. Phys. Tec. Sci., 3, 3-20.

21. Incropera, F.P., \& DeWitt, D.P. (2002). Fundamentals of Heat and Mass Transfer (5th Ed-n). New York: John Wiley \& Sons.

22. Menter, F.R. (1993). Zonal two-equation $k$ - $\omega$ turbulence models for aerodynamic flows, AIAA Paper 1993-2906.

\section{GAISA PLŪSMU UN TEMPERATŪRAS SADALĪJUMU SKAITLISKĀ MODELĒ ŠANA DZĪVOJAMĀ TELPĀ AR DAŽĀDIEM SILTUMA APMAIN̦AS NOSACĪJUMIEM}

\section{S. Gendelis, A. Jakovičs}

\section{K o p s a vilk u m s}

Atsevišķu telpu iekštelpu termisko apstākḷu un siltuma zudumu no tām skaitliskā modelēšana ir būtiska visas ēkas siltuma apmaiņas bilances un energoefektivitātes analīzes kontekstā. Iepriekš veiktie ēkas norobežojošo konstrukciju siltuma caurlaidības koeficientu mērījumi, tās telpu gaisa blīvējuma testi un termogrāfiskie apsekojumi ḷauj precīzāk uzdot dažādu faktoru ietekmi skaitliskajos aprēķinos. Rakstā tiek salīdzināti skaitliskie temperatūras un gaisa plūsmu sadalījumu aprēķinu rezultāti tipiskā dzīvojamā telpā, tiek analizēti telpas siltuma zudumi atšķ̧irīgu apkures veidu, dažādu ventilācijas nosacījumu un main̄̄gā solārā starojuma gadījumos. Papildus tiek novērtēti arī gaisa kustības ātrumi, temperatūra un tās gradients no termiskā komforta apstākḷu viedokḷa. Ir parādīts, ka visiem minētiem faktoriem ir izteikti atšķirīga, bet būtiska nozīme gan termiskā komforta apstākḷu veidošanā, gan telpas siltuma bilancē.

20.07.2010. 